certain that new regulatory bodies would solve the problem.

The Gelsinger case revealed a failure to report adverse events in gene-therapy trials. After his death, the National Institutes of Health (NIH) asked researchers using adenoviral vectors the delivery vehicle used in Gelsinger's trial - to report all adverse events.

Eventually, 652 became public (see Nature 403, 237; 2000), including several deaths not directly attributed to gene therapy. Last week's hearing revealed 40 more adverse events, related to vectors other than adenovirus.

Researchers are required to report "serious and unexpected" adverse events only to the FDA, although they must disclose all adverse effects to the NIH's Recombinant DNA Advisory Committee (RAC).

Former RAC chair LeRoy Walters, director of the Kennedy Institute of Ethics at Georgetown University, testified that NIH's 1996 reduction of the RAC's powers had sent a "mixed message" to researchers, possibly indicating that they were no longer required to report to the RAC.

Walters also said that problems in securing a patient's informed consent revealed "a system-wide problem not

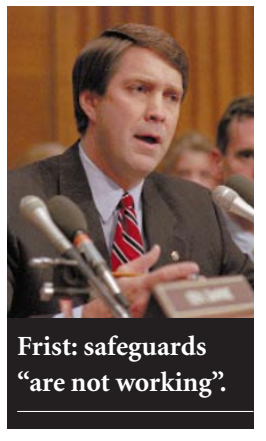
unique to gene therapy". Paul Gelsinger, the patient's father, testified that researchers had not told his son that two monkeys had died on the experimental treatment.

The researchers

had also incorrectly told Gelsinger that a previous subject had benefited from the gene therapy. The two problems were among 18 used by the FDA to to justify shutting down five other gene-therapy trials at the University of Pennsylvania (see Nature 403, 354; 2000).

More inspections may prevent future problems, said Michael Blaese, chief scientific officer of Kimeragen, a Pennsylvania-based biotechnology company. Blaese, previously a genetherapy researcher at the NIH, noted that trials on the NIH campus were audited frequently.

Jay Siegel, director of the FDA's Office of Therapeutics Research and Review, testified that the agency typically conducts on-site investigations as a drug or treatment nears approval. He said that the agency has begun to do spot checks at a "very limited" number of clinical sites. "We would like to do more." Paul Smaglik

\title{
Scientists reject blame for German genome shortfall
}

\section{Munich}

German scientists have rejected claims that lack of government funding for genome research is their own fault, for failing to convince politicians of its importance.

Although funding for the German Human Genome Project (DHGP) is expected to increase substantially next year, it will still fall well short of what many believe the country needs to compete internationally.

Walter Döllinger, a senior official in the research ministry, told a DHGP workshop last month that the scientific community and industry must share the blame for waning political support. Their lobbying activities have been ineffective, he said, and they have not put significant amounts of their own money into genomics research.

Döllinger said the research ministry is trying to maintain political momentum, which has slowed as government priorities changed. The ministry has drawn up a broad strategy paper for genome research that "covers the whole chain of innovation, from basic research to development". He expects it to be approved during the 2001 budget talks in June.

This extends an earlier paper, based on input from the scientific community, that was to have been launched last year. To the dismay of researchers, the paper was shelved, apparently because research minister Edelgard Bulmahn felt that it lacked a sufficiently strong political message to persuade the cabinet to provide the level of extra funding it demanded (see Nature 402, 706; 1999).

The present paper brings together all the ministry's activities in genome research, including its new DM100 million (US\$50 million) BioChance programme for start-up companies, along with the activities of research organizations such as the Deutsche Forschungsgemeinschaft (DFG), Germany's main granting agency, and the Helmholtz Society, which runs national research centres.

It proposes a "significant increase" possibly more than 50 per cent, Döllinger indicated - in project money for the DHGP, currently around DM50 million a year. The paper also proposes setting up a genomics programme for microorganisms and a fund for 'competence centres' to reward interdisciplinary programmes linking research groups from different institutions.

The new package would be more politically convincing than its predecessor, said Döllinger. But researchers say that its scientific aspirations will not be met unless the government supplies a lot more money.

Detlev Ganten, director of the Max

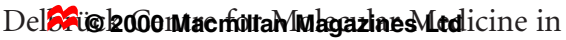
Berlin and head of the Helmholtz Society,

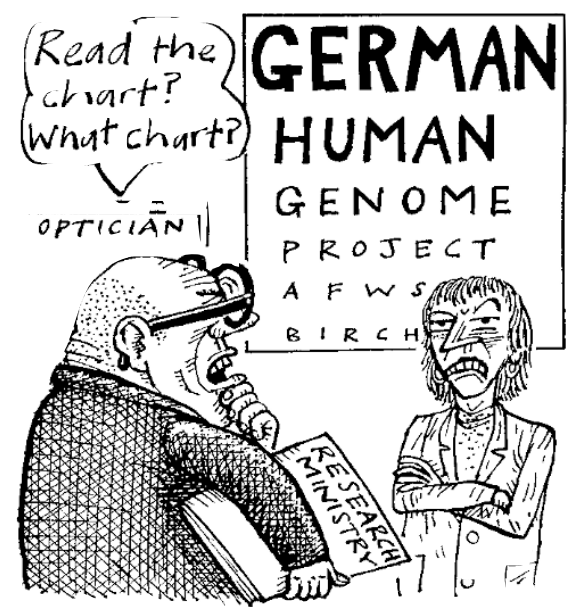

rejects Döllinger's claim that scientists have failed to shift funds from old areas of research. The Helmholtz Society has created a small strategy fund in genomics and intends to redistribute its own core funding in favour of genomics, he says. Its genome-related research will be evaluated next month by an international committee. The Helmholtz Society's senate will use the results in its decision on genomics strategies in May.

"The research ministry is very well aware of our activities," says Ganten. "It should not make up excuses to justify its own inactivity. It is naive to say that shifting our money would be sufficient; we need a lot of extra money."

The Helmholtz Society was a co-signatory of a report to the ministry which argued for a tenfold increase in public funding. Other signatories included major research organizations, such as the DFG, and the Förderverein, a consortium of German companies that support technology transfer from the DHGP.

DFG president Ernst-Ludwig Winnacker says he is "surprised" that Döllinger considers scientists' lobbying activities inadequate. He points out that the heads of all German research organizations have written detailed reports and campaigning letters to the ministry, and have launched an initiative to lobby parliamentarians.

"We have taken all opportunities to air the debate in newspapers and the most important political circles," says Winnacker. "Short of hiring a Zeppelin and flying it over Berlin, I'm not sure what more is expected of us."

Werner Schiebler, director of technology licensing and alliances at Aventis, says: "Industry recognizes its responsibility for supporting technology transfer and this is why we support the Förderverein by around DM1.5 million a year." But he adds that industry will only pay for basic research with clearly defined goals.

Alison Abbott 